\title{
PHYLOGEOGRAPHIC DISTRIBUTION OF Asperisporium caricae ISOLATES IN BRAZILIAN SOUTHEASTERN AND NORTHEASTERN COASTAL REGIONS
}

\author{
DISTRIBUIÇÃO FILOGEOGRÁFICA DE ISOLADOS DE Asperisporium caricae NO \\ LITORAL DO SUDESTE E NORDESTE BRASILEIRO
}

\begin{abstract}
Pedro Henrique Dias dos SANTOS ${ }^{1}$; Cláudia Roberta Ribeiro de OLIVEIRA ${ }^{2}$; Vivane Mirian Lanhellas GONÇALVES ${ }^{3}$; Fernanda Abreu Santana AREDES ${ }^{4}$; Beatriz Murizini CARVALHO ${ }^{5}$; Messias Gonzaga PEREIRA ${ }^{6}$; Silvaldo Felipe da SILVEIRA $^{7}$

1. Postdoctoral Researcher, Northern Rio de Janeiro State University, Department of Plant Breeding, Campos dos Goytacazes, State of Rio de Janeiro, Brazil. pedroh_dias@ @otmail.com; 2. Postdoctoral Researcher, Northern Rio de Janeiro State University, Department of Plant Breeding, Campos dos Goytacazes, State of Rio de Janeiro, Brazil; 3. Graduate Student, Northern Rio de Janeiro State University, Department of Plant Breeding, Campos dos Goytacazes, State of Rio de Janeiro, Brazil; 4. Postdoctoral Researcher, Northern Rio de Janeiro State University, Department of Plant Breeding, Campos dos Goytacazes, State of Rio de Janeiro, Brazil; 5. Ph.D Student, Northern Rio de Janeiro State University, Department of Plant Breeding, Campos dos Goytacazes, State of Rio de Janeiro, Brazil; 6. Ph.D Professor, Northern Rio de Janeiro State University, Department of Plant Breeding, Campos dos Goytacazes, State of Rio de Janeiro, Brazil. 7. Ph.D Professor, Northern Rio de Janeiro State University, Department of Entomology and Plant Pathology Campos dos Goytacazes, State of Rio de Janeiro, Brazil.
\end{abstract}

\begin{abstract}
Papaya (Carica papaya L.) is one of the main tropical fruits consumed in Brazil. The country is also one of the main papaya exporters, but one of the factors hindering its production lies on foliar diseases such as papaya black spot, which is caused by fungus Asperisporium caricae. This pathogen is widely distributed in the main producing regions of the Brazilian coastal area. Phylogeographic studies contribute to the knowledge about the genetic diversity and geographical distribution of genealogical lineages (haplotypes) and help better understanding the reproductive and evolutionary processes of closely related species or of a single species. Such information is useful in studies about phytopathogenic fungi because it enables identifying the most prevalent genealogical lineages in a given location, as well as inferring dispersal routes and providing information on the origin and frequency of exotic material introduction events. Results in this type of study can significantly help developing new disease control strategies. Literature still lacks studies on the Papaya x $A$. caricae pathosystem. Based on the phylogenetic and phylogeographic analysis applied to nucleotide sequences of the Internal transcribed spacer (ITS) gene, we herein address the genealogical and dispersal events recorded for this pathogen in order to better understand its evolution in, and adaptation to, Brazilian orchards. Three haplotypes were identified among the A. caricae isolates; their distribution was mostly related to the geographic distance between sample collection regions rather than to any reproductive or evolutionary processes presented by the species. The low variability among the herein studied isolates may result from the physiological specialization (survival exclusively associated with the host plant) and from the regional transport of contaminated fruits (with lesions and spores), besides the low contribution of reproductive events, which corroborate the lack of knowledge about the sexual stages of A. caricae.
\end{abstract}

KEYWORDS: Carica papaya. Papaya Black Spot. Evolutionary Models

\section{INTRODUCTION}

Papaya (Carica papaya L.) is one of the most cultivated and consumed fruits in the tropical and subtropical regions around the world due to its nutrition and digestive properties (WALL, 2006). Papaya black spot is caused by the fungus Asperisporium caricae (Speg.) Maubl. This disease can hinder crop yield, since it affects plant vigour by reducing its photosynthetic area. It also causes quantitative and qualitative damages that lead to the commercial depreciation of fruits (SANTOS;
BARRETO, 2003) and, consequently, affects the agriculture in the Country (SANTOS et al., 2017a).

There are reports about papaya plants infected by such fungus in different countries such as Brazil, where the black spot disease was first described by Maublanc (MAUBLANC, 1913) in Rio de Janeiro State. Since then, it has been described in several states such as Minas Gerais, Espírito Santo, São Paulo, Santa Catarina, Bahia (SILVA, 2010), Rio Grande do Norte and Amazonas (SOUZA et al., 2014). Assumingly, this fungus is distributed in almost all Brazilian regions 
where papaya plants are grown. However, little is known about the diversity of these isolates and about their distribution in the main Brazilian papaya producing regions.

A. caricae is inserted in the cercosporoid complex, although there is no evidence that it is a Mycosphaerella anamorph. Fungi belonging to the cercosporoid complex are hyphomycetes, many of them are anamorphous species belonging to genus Mycosphaerella. This complex comprises more than 20 genera of phytopathological importance. Literature lacks studies addressing the biology of this fungus probably due to the possible biotrophic condition of Asperisporium, which leads to growth, colony maintenance and sporulation difficulties in vitro. Most studies mainly focus on disease control strategies (SANTOS; BARRETO, 2003; VIVAS et al., 2015; SANTOS et al., 2017a).

Interactions between plant genotypes and fungal isolates throughout the evolution of living beings can bring harm to the host. It is possible setting effective disease control strategies when the variations between different pathogen isolates are known (SANTOS et al., 2017b). A practical example of it can be seen when fungi with pathogenic potential keep their ancestral ability to explore other hosts as endophytes. This ability reduces the success rate in crop rotations (FILIPE et al., 2012; STERGIOPOULOS; GORDON, 2014), since these pathogens can have endophytic action in secondary plants until the main host becomes available again.

Phylogeographic studies about fungi, although scarce, may contribute to the knowledge about the pathogen diversity and help understanding the geographical distribution of genealogical lineages, mainly of the ones within and among closely-related species (AVISE, 2000; SANTOS et al., 2017b). The literature still lacks studies relating the geographic and phylogenetic distribution of the fungal species $A$. caricae. The aim of the current study was to apply molecular strategies to help better understanding the $C$. papaya $x$ A caricae pathosystem, based on pathogen evolution, genetic variability, adaptation to the host and on the species' distribution and ancestral entrance in the main papaya producing Brazilian states.

\section{MATERIAL AND METHODS}

\section{Isolation, DNA Extraction and Sequencing}

We collected papaya leaves (fresh or dried in the shade) presenting black spot symptoms, but no sporulation caused by hyperparasite fungi, in different Brazilian regions comprising Bahia, Rio Grande do Norte, Rio de Janeiro, Espírito Santo, Minas Gerais and São Paulo states. We isolated 25 isolates of the pathogen from 30 samples (Table 1). Monosporic isolates were collected in colonies resulting from conidia germination in PDA (potatodextrose-agar) medium. The fungus grown in the same PDA medium, and their cultures, were incubated in growth chambers (BOD) at $25 \pm 2^{\circ} \mathrm{C}$, 12-h photoperiod, under 20W fluorescent light (cold white). We maintained and cultivated the cultures in the same medium, in sloped tubes. We deposited all the herein obtained pure cultures in the plant disease clinic collection of Universidade Estadual do Norte Fluminense Darcy Ribeiro.

Table 1. GenBank accession numbers of $A$. caricae DNA sequences used in the analyses

\begin{tabular}{lll}
\hline Isolate & County & ITS $^{\mathbf{1}}$ \\
\hline Northeast & & \\
\hline AC1 & Cruz das Almas/BA & MH014906 \\
AC2 & Cruz das Almas/BA & MH014907 \\
AC3 & Cruz das Almas/BA & MH014908 \\
AC4 & Cruz das Almas/BA & MH014909 \\
AC5 & Cruz das Almas/BA & MH014910 \\
AC6 & Mossoró/RN & MH014911 \\
AC7 & Mossoró/RN & MH014912 \\
\hline Southeast & & \\
\hline AC9 & Búzios/RJ & MH014913 \\
AC12 & Duque de Caxias/RJ & MH014914 \\
AC13 & Linhares/ES & MH014915 \\
AC14 & Ibiraçu/ES & MH014916
\end{tabular}




\begin{tabular}{lll} 
AC15 & Itaocara/RJ & MH014917 \\
AC16 & Ituverava/SP & MH014918 \\
AC17 & Janaúba/MG & MH014919 \\
AC19 & Mimoso/ES & MH014920 \\
AC21 & Alegre/ES & MH014921 \\
AC22 & Rio Bonito/RJ & MH014922 \\
AC23 & Mimoso/ES & MH014929 \\
AC24 & Rosário da Limeira/MG & MH014923 \\
AC25 & Campos dos Goytacazes/RJ & MH014924 \\
AC26 & Mimoso/ES & MH014925 \\
AC27 & Linhares/ES & MH014926 \\
AC28 & Linhares/ES & MH014927 \\
AC29 & Linhares/ES & MH014928 \\
AC30 & Campos dos Goytacazes/RJ & MH014930 \\
\hline
\end{tabular}

We macerated mycelium from pure cultures with a cell disruptor (Loccus L-Beader 3) based on instructions by Santos et al. (2017b), whereas other DNA extraction steps were based on Pinho et al. (2013). We applied Primers ITS5 and ITS4 (WHITE et al., 1990) to amplify the reactions in the Internal Transcribed Spacer (ITS) region and used the commercial purification system Agencourt AMPure XP (Magnetic Stand-96 Ambion) to purify the amplified products, based on the recommendations of the manufacturer. ACTGene Análises Moleculares Ltda (Centro de Biotecnologia, Universidade Federal do Rio Grande do Sul, Porto Alegre, RS, Brazil) was responsible for the sequencing procedure.

We edited the nucleotide sequences in the DNA Dragon software (HEPPERLE, 2011) and manually corrected all sequences. We corrected the arrangement of nucleotides at ambiguous positions through primer sequences in directions $5^{\prime}-3^{\prime}$ and 3'-5'. New sequences of each isolate were deposited in the GenBank database (http://www.ncbi.nlm.nih.gov) (Table 1).

\section{Haplotypical Distribution}

We conducted Bayesian inference (BI) analyses, based on the Markov Chain Monte Carlo (mcmc) method, to confirm the identity of the isolates and set the best nucleotide substitution model in the MrMODELTEST 2.3 software before launching the BI (POSADA; BUCKLEY, 2004). Once the likelihood scores were calculated, we selected the model based on the Akaike Information Criterion (AIC). We used the K80 evolution model.

We concluded the BI analysis in the MrBayes v.3.1.1 software (RONQUIST;
HUELSENBECK, 2003). We ran four MCMC chains simultaneously, starting from random trees for $10,000,000$ generations. We sampled the trees every 1,000 th generation for 10,000 trees, in total; the burnin was set at $25 \%$. The posterior probabilities (RANNALA; YANG, 1996) were based on a majority-rule consensus tree generated from the remaining 7,500 trees. We analyzed the likelihood $\log$ convergence in the TRACER software v. 1.4.1 (RAMBAUT; DRUMMOND, 2013), visualized the trees in FigTree (RAMBAUT, 2009) and exported the data to the graphic software. We rooted the trees with Amycosphaerella africana CBS 680.95 and CBS 134927.

We used the median-joining (MJ) algorithm for the ITS gene in the DnaSPv5 software to investigate phylogenetic relationships between haplotype-network populations to identify individual haplotypes and their frequencies(LIBRADO; ROZAS, 2009). We adopted the same software to estimate haplotype and nucleotide diversity (NEI, 1987).

\section{Population Structure}

We set the genetic structure of the herein studied population based on country region (genetic diversity within and between populations). We subjected samples grouped in populations deriving from Southeastern (SP, RJ, MG and ES) and Northeastern (BA and $\mathrm{RN}$ ) coastal regions to molecular variance analysis (AMOVA) in the ARLEQUIN v.3.1 software (EXCOFFIER et al., 2005).

We applied the Median-Joining (MJ) method to investigate genealogical relationships between haplotypes in the Network 4.6.0.0 software 
(Bandelt et al., 1999). The maximum number of parsimonious connections between sequences was estimated at $95 \%$ probability for all haplotype connections within the network. Haplotypes were presented in colour-coded circles and their sizes were proportional to the frequency of isolates in each haplotype.

We constructed a clustering analysis by associating the Bayesian approach and the phylogeographic grouping through the Bayesian Phylogeographic and Ecological Clustering (BPEC) method, based on Manolopoulou et al. (2011, 2016). We conducted the analysis in the R software $(\mathrm{R}$ DEVELOPMENT CORE TEAM, 2015) wherein the following parameters were set: $\mathrm{ds}=3$ (parsimonious relaxation parameter), maximum number of migrations $=3$, and 50 million steps in the MCMC.

\section{RESULTS}

\section{Haplotypical Distribution}

The Internal Transcribed Spacer (ITS) region, sequenced for $25 \mathrm{~A}$. caricae isolates, resulted in 308 bp fragments; we deposited all sequences in the GenBank (Table 1). Phylogenetic analysis was the instrument applied to 37 taxa; the sequence alignment totaled 341 characters, 19 of them were informative for parsimony, 20 were varying and 321 were conserved. Based on the phylogenetic analysis, we identified isolates at species level; these isolates were allocated to the $A$. caricae clade, which was well supported by posterior probability $(\mathrm{pp})=1.0$ (Figure 1). The alignment showed 4 polymorphic sites, besides enabling the identification of only 3 haplotypes in the sampled population. Such outcome characterized low haplotype $(H=0.22 \pm 0.106)$ and nucleotide $(\pi$ $=0.0013 \pm 0.0034$ ) diversity (Table 2 ).

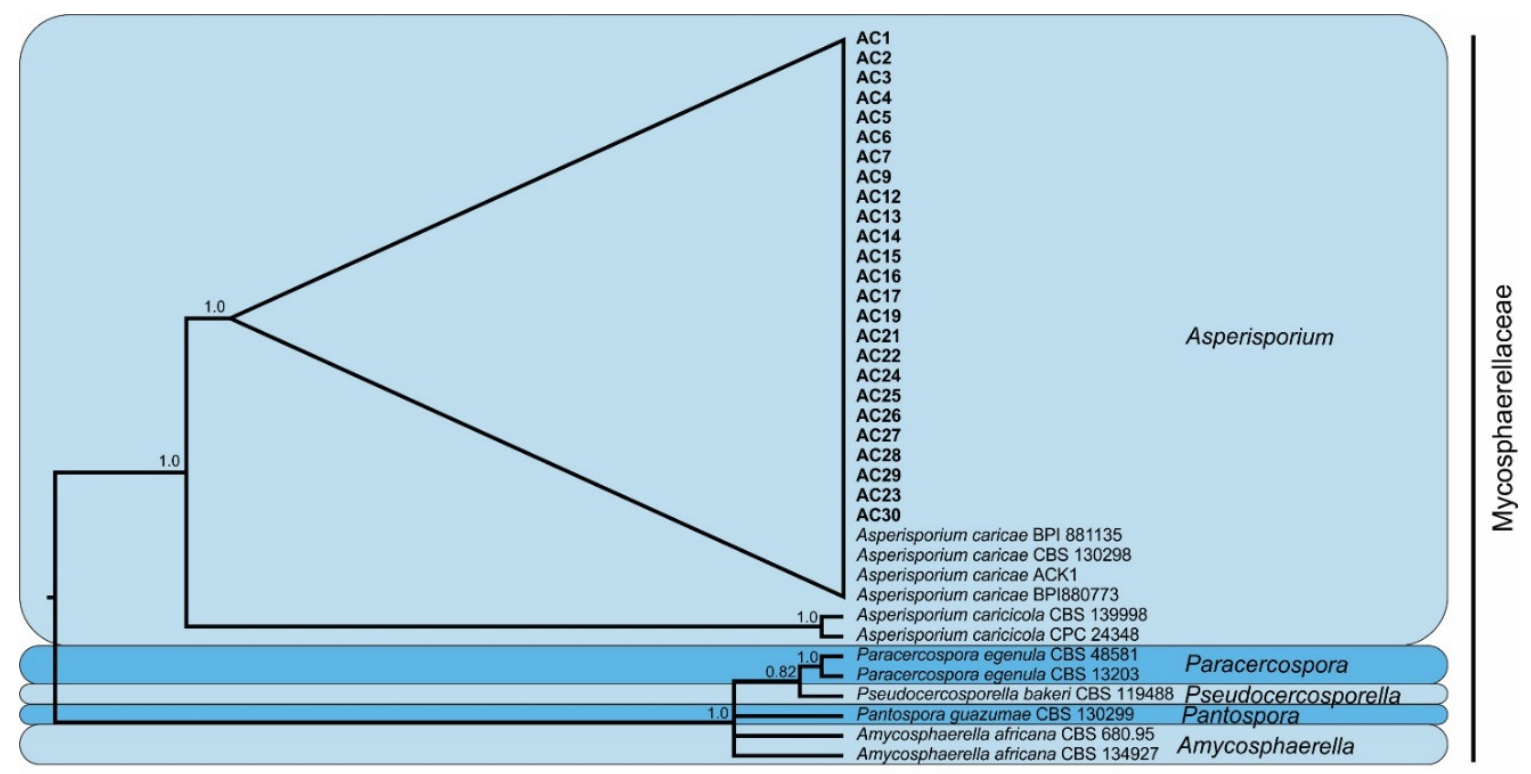

Figure 1. Phylogenetic tree based on the Bayesian Inference of sequences from the Internal Transcribed Spacers (ITS) region of Asperisporium caricae isolates associated with Papaya. The posterior probability is indicated near the branch nodes. The tree was rooted in Amycosphaerella africana CBS 680.95 and CBS 134927.

Table 2. Haplotype $(H)$ and Nucleotide diversity $(\pi)$, and their respective standard deviations (SD) in A. caricae found in Brazilian Northeastern and Southeastern regions

\begin{tabular}{llccllllll}
\hline Region & \multirow{2}{*}{$\mathrm{N}^{*}$} & $\mathrm{~S}$ & $\mathrm{~K}$ & $H(\mathrm{SD})$ & $\pi(\mathrm{SD})$ & \multicolumn{3}{c}{ Haplotype Frequency } \\
\cline { 7 - 9 } Northeastern & 7 & 1 & 2 & $\begin{array}{l}0.28 \\
(0.196)\end{array}$ & $\begin{array}{l}0.0009 \\
(0.0006)\end{array}$ & 6 & 1 & - & 7 \\
Southeastern & 18 & 4 & 3 & $\begin{array}{l}0.22 \\
(0.124)\end{array}$ & $\begin{array}{l}0.0014 \\
(0.0009)\end{array}$ & 16 & 1 & 1 & 18 \\
\hline Total & 25 & 4 & 3 & $\begin{array}{l}0.22 \\
(0.106)\end{array}$ & $\begin{array}{l}0.0013 \\
(0.0034)\end{array}$ & 22 & 2 & 1 & 25
\end{tabular}

* $\mathrm{N}=$ number of individuals; $\mathrm{S}=$ number of polymorphic sites; and $\mathrm{K}=$ number of haplotypes.

The haplotype network represented in

Figure 2B presents three distinct haplotypes identified in the Internal Transcribed Spacer (ITS) region, based on the median joining method. We did 
not observe haplotype distribution in the studied regions, i.e., the same haplotypes were observed in both the Southeastern and Northeastern coastal regions, except for haplotype $\mathrm{H} 3$, which was only found in the Southeastern region (Figure 2A). Haplotype $\mathrm{H} 1$ was most often found in both herein studied regions, whereas haplotype $\mathrm{H} 2$ was more common in the Northeastern than in the Southeastern region (Figure 2 and Table 2). According to the haplotype network, haplotype $\mathrm{H} 3$ presented a larger number of mutations than the most often recorded haplotype(H1) (Figure 2B).
A

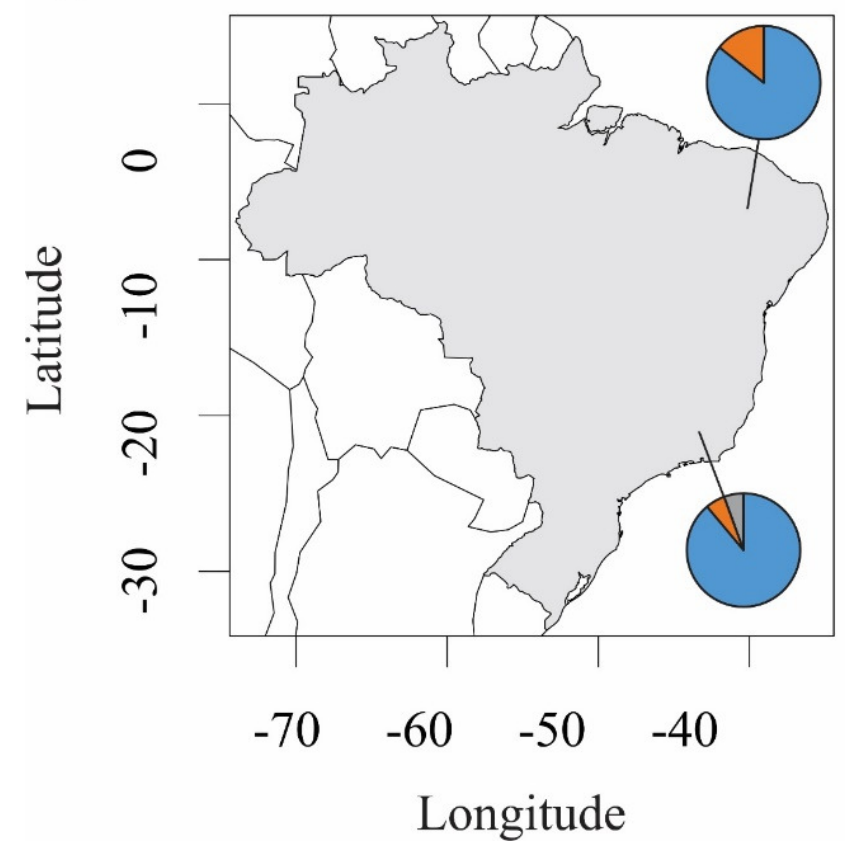

B

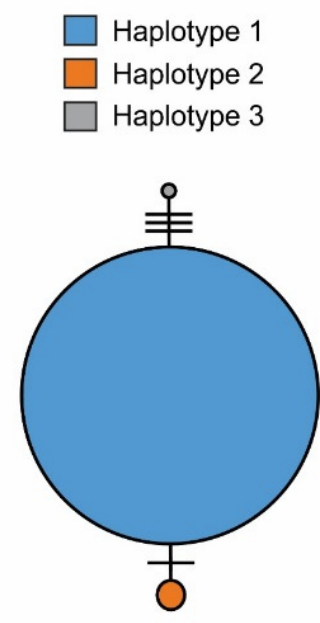

Figure 2. Distribution patterns of A. caricae haplotypes. (A) Frequency of haplotypes in the Internal Transcribed Space (ITS) region and (B) haplotype network obtained through median joinning. The size of the graphs is proportional to the number of isolates in each haplotype.

\section{Population Structure}

The AMOVA results, the variation within populations was understood in its totality (Table 3). The Fst value was negative; thus, it remained as null value, according to Wright $(1951,1965)$, It did not lead to statistical significance in the frequency of the analyzed sequences $(\mathrm{p}>0.05)$

Table 3. Molecular variance analysis (AMOVA) applied to A. caricae isolates deriving from different places in Brazilian Southeastern (SP, RJ, MG and ES states) and Northeastern (Bahia and RN states) coastal regions.

\begin{tabular}{llllll}
\hline Source & d.f. & Sum of Squares & Variance components & Variation (\%) & Fst \\
\hline Between Populations & 1 & 0.085 & -0.01155 & 0.0 & 0.0 \\
Within Populations & 23 & 4.63 & 0.20152 & 100 & \\
\hline Total & 24 & 4.72 & 0.18997 & & \\
\hline
\end{tabular}

The BPEC analysis identified four clusters; the highest posterior probability values were recorded for the Southeastern region. Among the observed clusters, two derived from the Brazilian Southeast region, and two, from the Northeastern region. The three sites most likely to be ancestors were located at the intersection between the green and blue clusters, which were highlighted by white arrows (Figure 3). In other words, the BPEC analyses attributed haplotypes to four phylogeographic groups and divided the regions in two groups. 


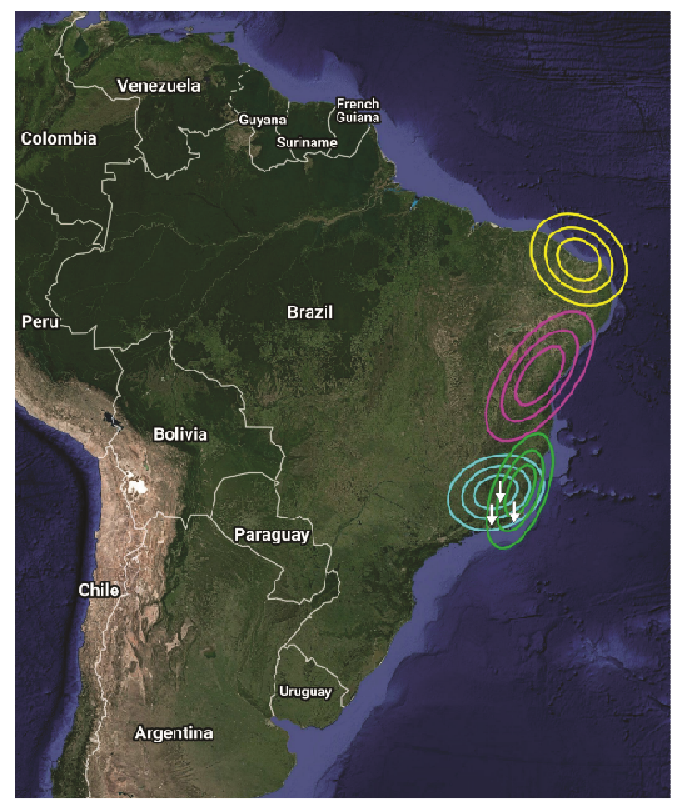

Figure 3. Bayesian phylogenetic and ecological clustering analyses (BPEC). Each colored contour plot indicates a different phylogeographic grouping. The contour plots are placed at the 'center' of each population cluster, and the coloured regions show the radius of 50\% concentration contours around it. White arrows show the ancestral locations presenting the highest probability calculated.

\section{DISCUSSION}

The low diversity indices recorded for the Northeastern and Southeastern regions suggested the occurrence of a founding effect. This evolution phenomenon results from the settling of a new population by few original founders (MAYR, 1940; FUTUYMA, 2006). The aforementioned phenomenon was evidenced in our study by two main aspects of the herein investigated fungus: lack of knowledge about its teleomorph stage and about its parasitic relation with the host plant. Moreover, A. caricae is a highly-specialized pathogen that may not survive in the field when there is lack of host plants - such outcome leads to low genetic variation (MINNIS et al., 2011; CROUS et al., 2015; VIDEIRA et al., 2017).

Haplotypes located in the center of the network are ancestors, whereas the ones located at the extremities are deriving or ancestral haplotypes (FREIRE; OLIVEIRA, 2008; SANTOS et al., 2017b). "H1" stood out as the most central haplotype in the herein obtained network (Figure 2B), besides being the most frequent haplotype in it, fact that reinforced its ancestry. Haplotype H1 showed ramifications towards two other haplotypes located in the end of the network (Figure 2B). According to Templeton et al. (1992) and Freire and Oliveira (2008), ramifications in the networks are directly associated with haplotype mutations that take place at different stages in their evolution, besides generating descending haplotypes (TEMPLETON, 1998; FREIRE; OLIVEIRA, 2008; SANTOS et al., 2017b).

The biotrophic fungus $A$. caricae is cosmopolitan due to the wide distribution and commercialization of host species such as Carica papaya in tropical regions (BAUTISTA-BAÑOS et al., 2013; VIVAS et al., 2016; VIDEIRA et al., 2017), fact that explains the low genetic diversity and wide distribution of haplotypes in the country (Figure 2A; Tables 2 and 3). Its wide distribution in Brazilian coastal regions is directly linked to papaya production sites. High host specificities may have negatively contributed to pathogen settling in other places.

Variation within populations (Table 4) can be closely related to the frequent movement of pathogen inoculum in different geographic locations, since most of the investigated regions were papaya producers and populations shared Haplotype H1 (Table 2). Such outcome substantiates the slight differences between populations (Table 3). The Fst values (Table 3) were negative because the Wright estimator (WRIGHT, 1965) was biased towards small samples. Thus, in order to solve this problem, software such as Arlequim (EXCOFFIER et al., 2005) adopt the Weir \& Cockerham method (WEIR; COCKERHAM, 1984) to allow negative results in 
some loci in order to compensate overestimates in others. Although rare, negative locus means indicate that the variation between individuals within populations is higher than between populations (HOLSINGER; WEIR, 2009). Low Fst values increase the gene flow; therefore, negative Fst values may indicate high genetic exchange between populations.

The three sites designated as pathogen ancestors (Figure 3) can be seen as the initial inoculum entry in Brazil; they correspond to Rio de Janeiro ( $\mathrm{pp}=60 \%$ ) with two sites and Espírito Santo $(\mathrm{pp}=24 \%)$ states, with one site. However, we must condition any conclusions drawn from these inferences to their associated-probability values., There is higher uncertainty about $A$. caricae inferences due to limited data information rather than to convergence issues. Additional sampling (more locations and more individuals per location) may help improving posterior probabilities. According to Manolopoulou (2016), it is possible developing BPEC scripts capable of incorporating group sequences to the inference of ancestral haplotypes in order to improve posterior probabilities for ancestral areas.

Data about phytopathogen dispersion across geographic locations are essential to help planning management strategies such as the identification of the pathogen entry site, which can help explaining the way the pathogen settles in a given region. In addition, genetic variations can differentiate the pathogen's response to different control strategies. Therefore, our study showed that the low A. caricae variability and its population structure, in association with the geographic distance, which is linked to the biotrophic characteristic of the fungus and to the wide distribution and commercialization of host species, favors the control of this fungus in papaya plants. It happens because high-variability pathogens develop evolutionary strategies to remain in the population, because the adaptability of certain organisms depends on their genetic variability.

RESUMO: O mamoeiro (Carica papaya L.), é uma das principais frutas tropicais consumidas no Brasil. O país é um dos principais exportadores de mamão e um dos gargalos da produção mundial está diretamente ligado à ocorrência de doenças foliares, podendo-se destacar a pinta-preta do mamoeiro, causada pelo fungo Asperisporium caricae. O patógeno está amplamente distribuído nas principais regiões produtoras, as quais englobam grande parte do litoral Brasileiro. Estudos filogeográficos contribuem não só para o conhecimento da diversidade genética e da distribuição geográfica das linhagens genealógicas (haplótipos), como também contribuem para o conhecimento dos processos reprodutivos e evolutivos de uma espécie ou de espécies estreitamente relacionadas. No estudo de fungos fitopatogênicos, tais informações são úteis para identificar linhagens genealógicas mais prevalentes em um determinado local, inferir as rotas de dispersão e fornecer informações sobre a origem e frequência dos eventos de introdução de material exótico. Este tipo de estudo produz resultados que podem colaborar significativamente na elaboração de novas estratégias de controle da doença. Não existe, até o presente momento, este tipo de estudo para o patossistema Mamoeiro x $A$. caricae. Neste trabalho, por meio da análise filogenética e filogeográfica, a partir de sequências nucleotídicas do gene Internal transcribed spacer (ITS), discutimos os eventos genealógicos e de dispersão deste patógeno com o intuito de compreender melhor sua evolução e adaptação nos pomares brasileiros. Dentre os isolados de A. caricae foram identificados 3 haplótipos, sendo sua distribuição relacionada mais ao distanciamento geográfico das regiões das coletas das amostras do que a eventuais processos reprodutivos ou evolutivos da espécie. Acredita-se que a baixa variabilidade dentre os isolados estudados seja explicada pela especialização fisiológica (sobrevivência exclusivamente associada à planta hospedeira) e ao transporte regional de frutos contaminados (com lesões e esporos), sendo baixa a contribuição de eventos reprodutivos, o que corrobora o desconhecimento de fase sexual de $A$. caricae.

PALAVRAS CHAVE: Carica papaya. Pinta Preta do Mamoeiro. Modelos Evolutivos.

\section{REFERENCES}

AVISE, John Charles Phylogeography : the history and formation of species. 1. ed. Cambridge: Harvard University Press, 2000. 447p. 
BAUTISTA-BAÑOS, S.; SIVAKUMAR, D.; BELLO-PÉREZ, A.; VILLANUEVA-ARCE, R.;

HERNÁNDEZ-LÓPEZ, M. A review of the management alternatives for controlling fungi on papaya fruit during the postharvest supply chain. Crop Protection, v. 49, p. 8-20, 2013. https://doi.org/

10.1016/j.cropro.2013.02.011

CROUS, P. W.; SCHUMACHER, R. K.; WINGFIELD, M. J.; SCHUMACHER, R. K.; WINGFIELD, M. J.; LOMBARD, L.; GIRALDO, A.; CHRISTENSEN, M.; GARDIENNET, A.; NAKASHIMA, C.; PEREIRA, O. L.; SMITH, A. J.; GROENEWALD, J. Z. Fungal Systematics and Evolution : FUSE 1. Sydowia, v. 67, p. 81118, 2015. https://doi.org/ 10.12905/0380.sydowia67-2015-0081

EXCOFFIER, L.; LAVAL, G.; SCHNEIDER, S. Arlequin (version 3.0): an integrated software package for population genetics data analysis. Evolutionary bioinformatics online, v. 1, p. 47-50, 2005. https://doi.org/ 10.1111/j.1755-0998.2010.02847.x https://doi.org/10.1177/117693430500100003

FILIPE, J. A. N.; COBB, R. C.; MEENTEMEYER, R. K.; LEE, C. A.; VALACHOVIC, Y.S.;COOK, A. R.; RIZZO, D. M.; GILLIGAN, C. A. Landscape Epidemiology and Control of Pathogens with Cryptic and LongDistance Dispersal: Sudden Oak Death in Northern Californian Forests. (D. L. Smith, Ed.)PLoS

Computational Biology, v. 8, n. 1, p. e1002328, 2012. https://doi.org/ 10.1371/journal.pcbi.1002328

FREIRE, M.; OLIVEIRA, L. Evolutionary history of Phakopsora pachyrhizi (the Asian soybean rust) in Brazil based on nucleotide sequences of the internal transcribed spacer region of. Genetics and Molecular Biology, v. 931, p. 920-931, 2008. https://doi.org/ 10.1590/s1415-47572008005000026

FUTUYMA, D. J. Ernst Mayr, genetics and speciation. Trends in Ecology \& Evolution, v. 21, n. 1, p. 7-8, 2006. https://doi.org/ 10.1016/j.tree.2005.10.001

HEPPERLE, D. DNA Dragon 1.4.1 - DNA Sequence Contig Assembler Software. , 2011.

HOLSINGER, K. E.; WEIR, B. S. Genetics in geographically structured populations: defining, estimating and interpreting FST. Nature Reviews Genetics, v. 10, n. 9, p. 639-650, 2009.

https://doi.org/ 10.1038/nrg2611

LIBRADO, P.; ROZAS, J. DnaSP v5: A software for comprehensive analysis of DNA polymorphism data. Bioinformatics, v. 25, n. 11, p. 1451-1452, 2009. https://doi.org/10.1093/bioinformatics/btp187

MANOLOPOULOU, I.; HILLE, A.; EMERSON, B. BPEC: An R Package for Bayesian Phylogeographic and Ecological Clustering. Journal of Statistical Software, v. VV, p. 1-32, 2016.

MANOLOPOULOU, I.; LEGARRETA, L.; EMERSON, B. C.; BROOKS, S.; TAVARE, S. A Bayesian approach to phylogeographic clustering. Interface Focus, v. 1, n. 6, p. 909-921, 2011.

https://doi.org/10.1098/rsfs.2011.0054

MAUBLANC, A. Sur une maladie de feuilles du papayer (Carica papaya). Mycologique de France, v. 29, p. 353-358, 1913.

MAYR, E. Speciation Phenomena in Birds. The American Naturalist, v. 74, n. 752, p. 249-278, 1940. https://doi.org/10.1086/280892

MINNIS, A. M.; KENNEDY, A. H.; GRENIER, D. B.; REHNER, S. A.; BISCHOFF, J. F. Asperisporium and Pantospora (Mycosphaerellaceae): epitypifications and phylogenetic placement. Persoonia - Molecular Phylogeny and Evolution of Fungi, v. 27, n. 1, p. 1-8, 2011. https://doi.org/10.3767/003158511X602071

NEI, Masatoshi. Molecular Evolutionary Genetics. 1. ed. New York: Columbia University Press, 1987. 512 p. https://doi.org/10.7312/nei-92038 
PINHO, D. B.; DUTRA, D. C.; PEREIRA, O. L. Notes on Ceratocystis paradoxa causing internal post-harvest rot disease on immature coconut in Brazil. Tropical Plant Pathology, v. 38, p. 152-157, 2013. https://doi.org/10.1590/S1982-56762013000200010

POSADA, D.; BUCKLEY, T. R. Model selection and model averaging in phylogenetics: advantages of akaike information criterion and bayesian approaches over likelihood ratio tests. Systematic biology, v. 53, n. 5, p. 793-808, 2004. https://doi.org/10.1080/10635150490522304

R DEVELOPMENT CORE TEAM. R: A Language and Environment for Statistical Computing. R Foundation for Statistical Computing Vienna Austria, 2015.

RAMBAUT, A. FigTree, a graphical viewer of phylogenetic trees. Institute of Evolutionary Biology University of Edinburgh, 2009.

RAMBAUT, A.; DRUMMOND, A. J. Tracer v1.6. Available from http://tree.bio.ed.ac.uk/software/tracer/, 2013.

RANNALA, B.; YANG, Z. Probability distribution of molecular evolutionary trees: a new method of phylogenetic inference. Journal of molecular evolution, v. 43, n. 3, p. 304-311, 1996.

https://doi.org/10.1007/BF02338839

RONQUIST, F.; HUELSENBECK, J. P. MrBayes 3: Bayesian phylogenetic inference under mixed models. Bioinformatics, v. 19, n. 12, p. 1572-1574, 2003. https://doi.org/10.1093/bioinformatics/btg180

SANTOS, M. C.; BARRETO, M. Estudo epidemiológico da varíola do mamoeiro em cultivares submetidos a tratamentos com fungicidas. Summa phytopatológica, v. 29, n. 2, p. 141-146, 2003.

SANTOS, P. H. D.; CARVALHO, B. M.; AGUIAR, K. P.; AREDES, F. A. S.; POLTRONIERI, T. P. S.; VIVAS, J. M. S.; MUSSI-DIAS, V.; BEZERRA, G. A.; PINHO, D. B.; PEREIRA, M. G.; SILVEIRA, S. F. Phylogeography and population structure analysis reveals diversity by mutations in Lasiodiplodia theobromae with distinct sources of selection. Genetics and Molecular Research, v. 16, n. 2, p. 1-14, 2017b. https://doi.org/10.4238/gmr16029681

SANTOS, P. H. D.; SILVEIRA, S. F.; VIVAS, M.; CARVALHO, B. M.; PEREIRA, M. G. Alternative control to black spot disease in papaya genotypes. Summa Phytopathologica, v. 43, n. 1, p. 60-62, 2017a. https://doi.org/10.1590/0100-5405/2208

SILVA, Larissa Gomes. Isolamento e crescimento de Asperisporuim caricae e sua relação filogenética com Mycosphaerellaceae. 2010. 58 f. Dissertação (Mestrado em Fitopatologia) - Curso de Pós-Graduação em Fitopatologia, Universidade Federal de Viçosa, Viçosa, 2010.

SOUZA, M. G. DE; PEREIRA, J. C. R.; BRIOSO, M. V. B. G. C. K. PAULO S. T. Primeiro relato de PintaPreta, causada por Asperisporium caricae, em mamoeiro no Amazonas. Comunicado Técnico, v. 109, p. 1-4, 2014.

STERGIOPOULOS, I.; GORDON, T. R. Cryptic fungal infections: the hidden agenda of plant pathogens. Frontiers in plant science, v. 5, p. 506, 2014. https://doi.org/10.3389/fpls.2014.00506

TEMPLETON, A. R. Nested clade analyses of phylogeographic data: Testing hypotheses about gene flow and population history. Molecular Ecology, v. 7, n. 4, p. 381-397, 1998.

https://doi.org/10.1046/j.1365-294x.1998.00308.x

VIDEIRA, S. I. R.; GROENEWALD, J. Z.; NAKASHIMA, C.; BRAUN, U.; BARRETO, R.W.; de WIT, P.J.G.M.; CROUS, P.W.. Mycosphaerellaceae - Chaos or clarity? Studies in Mycology, v. 87, p. 257-421, 2017. https://doi.org/10.1016/j.simyco.2017.09.003 
VIVAS, M.; RAMOS, H. C. C.; SANTOS, P. H. D.; SILVEIRA, S. F.; PEREIRA, T. N. S.; do AMARAL, A. T.; PEREIRA, M. G. Heterosis and genetic diversity for selection of papaya hybrids for resistance to black spot and phoma spot. Tropical Plant Pathology, v. 41, n. 6, p. 380-389, 2016. https://doi.org/10.1007/s40858-0160109-1

VIVAS, M.; SILVEIRA, S. F.; PIO-VIANA, A.; AMARAL, A. T.; FERREGUETTI, G. A.; PEREIRA, M. G. Resistance to multiple foliar diseases in papaya genotypes in Brazil. Crop Protection, v. 71, p. 138-143, 2015. https://doi.org/10.1016/j.cropro.2015.02.007

WALL, M. M. Ascorbic acid, vitamin A, and mineral composition of banana (Musa sp.) and papaya (Carica papaya) cultivars grown in Hawaii. Journal of Food Composition and Analysis, v. 19, n. 5, p. 434445, 2006. https://doi.org/10.1016/j.jfca.2006.01.002

WEIR, B. S.; COCKERHAM, C. C. Estimating F-Statistics for the Analysis of Population Structure. Evolution, v. 38, n. 6, p. 1358, 1984. https://doi.org/10.2307/2408641

WHITE, T. J.; BRUNS, T.; LEE, S.; TAYLOR, J. Amplification and direct sequencing of fungal ribosomal rna genes for phylogenetics. In: INNIS, M.; GELFAND, D.; SNINSKY, J.; WHITE, T. (Ed.). PCR - Protocols and Applications - A Laboratory Manual. London: Academic Press,1990. p.315-322. https://doi.org/10.1016/B978-0-12-372180-8.50042-1

WRIGHT, S. The genetical structure of natural populations. Ann. of Eugenics, v. 15, p. 323-354, 1951. https://doi.org/10.1111/j.1469-1809.1949.tb02451.x

WRIGHT, S. The Interpretation of Population Structure by F-Statistics with Special Regard to Systems of Mating. Evolution, v. 19, n. 3, p. 395, 1965. https://doi.org/10.2307/2406450 